\title{
EU Regional Policy and the Stimulation of Innovation: The Role of the European Regional Development Fund in the Objective 1 Region Burgenland
}

\author{
ALEXANDER KAUFMANN and PETRA WAGNER
}

\begin{abstract}
Alexander Kaufmann, ARC systems research GmbH, Seibersdorf, Austria. E-mail:
alexander.kaufmann@arcs.ac.at

Petra Wagner, ARC systems research GmbH, Seibersdorf, Austria. E-mail: petra.wagner@arcs.ac.at
\end{abstract}

\begin{abstract}
In recent years regional policy has become more and more concerned with the improvement of the innovation capacity and performance of firms. Many regional development strategies have as key elements the support of their regional innovation systems and innovative clusters of firms. It has been recognized that increasing the technological level, the value added and the competitiveness of a regional economy relies to a large extent on the innovation capacity of regional firms and clusters. Regional development is an important policy issue also for the European Union. The EU Structural Funds aim at supporting regions lagging behind in their development or facing structural problems. In this paper we are going to analyse how the European Regional Development Fund (ERDF) affects innovation in the Austrian Objective 1 region Burgenland. In this case study we use data from an innovation survey conducted in the context of the recent mid-term evaluation in order to assess the innovation-related effects of the ERDF. The analysis leads to the conclusion that the ERDF does not target the problems and needs of regional firms regarding innovation in a satisfactory way which also hampers the successful restructuring of the regional economy.
\end{abstract}




\section{Introduction}

In this paper we are investigating whether the European Union's regional policy plays a role in increasing the innovation potential of a regional economy based on a specific case, the Objective 1 programme Burgenland in Austria. We are interested in this question because fostering the development of regions confronted with structural deficiencies needs to target the innovation potential of the regional economy. Changing the structure of an economy - by setting up new firms, entering new markets and diversifying established firms - is closely linked with innovation, ranging from simple product modifications to products which are new to the market. As a consequence, regional policy in general and the EU's Structural Funds in particular should aim at improving the innovation capacity of firms in regions with lagging development.

Research findings on the effects of EU regional policy on the economic structure of poorer regions are ambiguous. In a recent paper, Midelfart-Knarvik and Overman (2002) have argued that structural spending by the EU does attract R\&D-intensive industries but often contrary to the comparative advantages of these regions. Such isolated "successes" do not lead to an improvement of the performance of the overall regional economy. Two thirds of the Objective 1 regions could not increase their share in the total value-added of the EU. Most of those which could, became more specialized according to their comparative advantages. They conclude that EU aid should be more focused on changing the endowments (the skills of the labour force) of regions and enabling specialization according to the resulting advantages. But this argument assumes that EU Structural Funds do have effects on changing crucial factors of competitiveness. In this paper we will present evidence that it is exactly the lack of such effects, on innovation in particular, that is characterizing EU regional aid.

We will deal with the limited effects of structural funding on innovation focusing on the particular case of the Objective 1 programme of the Austrian province Burgenland. In the course of the recent mid-term evaluation of this programme we have analysed the measures co-financed by the European Regional Development Fund (ERDF) trying to assess their potential effects on the innovation performance and capacity of the regional economy. Burgenland is the least developed province of Austria. For decades it has been suffering from its peripheral location not only within Austria but also from locational disadvantages as a border region to the former Eastern block (the so-called "iron curtain" to Hungary and Slovakia). With Austria's accession to the European Union in 1995, Burgenland was granted Objective 1 status to stimulate structural change from a peripheral rural area to a modern central European region, particularly in view of the accession of its neighbours Hungary and Slovakia in 2004.

In the following, we will discuss the relationship between regional development, structural economic change and innovation (section 2), give an overview of the role of innovation-oriented measures in ongoing Objective 1 programmes (section 3) and analyse the case of Burgenland's Objective 1 programme in more detail (section 4) - in particular, whether the ERDF-supported measures are targeting the most important problems and needs of regional firms regarding their innovation activities. Finally, we will present our conclusions regarding the reasons of the limited effects of structural funding in stimulating innovation and some general proposals how the effectiveness might be improved (section 5). 


\section{On the Relationship between Regional Development and Innovation}

It has been generally recognized that research, technology and innovation policy concerns many other policies, one of them being regional policy (Grande, 2001). In the Green Paper on Innovation, the European Commission (1995) lists regional policy besides industrial policy, research and technological development (RTD) policy, education and training, tax policy, competition policy, policy support for SMEs and environmental policy as necessary to strengthen the capacity for innovation. This, of course, requires highly effective coordination procedures which, especially at the level of the European Union, do not yet exist (Grande, 2001). The regional dimension of innovation, research and development, the importance of spatial and relational proximity in innovation processes, has been explicitly considered in approaches like 'innovative milieu' (Aydalot, 1988) and 'regional innovation system' (Braczyk et al., 1998), to mention only a few.

The interrelation of regional development and innovation has also been recognized by regional policy-making, both at the national and the European level. Many European Union activities to support regional development have a strong focus on improving innovation performance, either directly by supporting RTD projects or indirectly by upgrading innovation-related infrastructure (see also chapter 3). Structural change, leading to a higher share of more competitive and higher valued-added industries, is nearly impossible without an innovative business sector. Structural change is to a large extent endogenous, being the result of two processes: start-ups and changes of business activity (see figure 1). Setting up new firms in attractive industries while closing down firms in declining industries transforms the industrial structure into the desired direction. Of course, structural change is not exclusively linked with birth and death of organizational entities. Also existing firms are able to change their business activity, shifting their focus from declining to expanding markets. In addition, structural change can also be "imported" from abroad via foreign direct investment. The exogenous influence is not limited to establishing subsidiaries but also includes subcontracting to local firms. In any way, attracting foreign direct investment in high-wage countries is hardly possible without offering location factors that support innovation (research organizations, highly qualified workforce, suitable suppliers etc.). Figure 1 summarizes the alternative ways of structural change of an economy, calling the decreasing sector 'mature' and the increasing sector 'modern'.

\section{$=>$ FIGURE 1}

Regional policy and innovation policy are strongly interlinked, but may also contradict each other. The aim of regional policy is to balance disparities and to support the growth of dynamic sectors in lagging regions. However, localization and urbanization economies are highly important for innovative firms, therefore these firms tend to agglomerate in clusters which may reinforce disparity. One example of this policy dilemma is the BioRegio contest in Germany where only already strong regions were selected for public support of biotechnology clusters (Dohse, 2000).

Because regional and innovation policies are not independent, proposals to define specialized roles for regional and RTD policies in pursuing the shared objective of 
strengthening competitiveness and innovation - i.e. improving the capacity to do research and to adopt results of research as the task of regional policy while supporting the actual research process as the task of RTD policy (e.g. Sharp, 1998) - will not work. It is necessary to integrate regional development and innovation strategies. For such an integrated approach innovation-oriented policy at the regional level needs coordination with other regions, at the national and, with increasing importance, at the European level. Accepting the fact that regions have their specific comparative advantages and that it is therefore reasonable that regions specialize on specific fields of technological development or innovative clusters is the precondition for such a coordinated approach. This is particularly important for less developed regions because of their specific needs and their competitive disadvantage compared with more developed regions. Of course, finding a viable compromise between several regions' ambitions is a very challenging task, usually going beyond national borders, concerning the European Union and its regional policy. Reforms of the European cohesion policy for the next period (2007 - 2013) are proposed in the Third Cohesion report of the European Commission (2004), but the potential conflict between innovation-induced concentration on the one hand and cohesion on the other as well as the necessity to integrate regional innovation strategies do not seem to have been fully recognized.

\section{Innovation-oriented Measures in Objective 1 Programmes}

Before we are going to deal with innovation-oriented measures in Objective 1 programmes financed by the European Regional Development Fund, a brief overview of the objectives and the organization of the European Union's regional policy is useful. A total of 195 billion $€$ are allocated for the improvement of the economic situation of the EU's less favoured regions through the Structural Funds for the period 2000 to 2006. By far most of these funds, 94\%, are concentrated on three priority objectives: Objective 1 concerns the support of areas lagging behind in their development, i.e. areas with a gross domestic product (GDP) of less than $75 \%$ of the Community average. This is the main priority of the European Union's regional policy. More than two thirds of the appropriations of the Structural Funds (over 135 billion $€$ ) are allocated to Objective 1 regions. Objective 2 supports economic and social conversion of areas facing various structural weaknesses. Objectives 1 and 2 are territorial programmes. Objective 3 aims at modernising systems of training and promoting employment without territorial restrictions (Inforegio, 2004a).

Financing the respective programmes is the task of four organizations, the so-called 'Structural Funds': The European Regional Development Fund (ERDF) finances infrastructure, job-creating investments, local development projects and aid for small and medium-sized firms (SMEs). The ERDF is also primarily responsible for supporting innovation, e.g. directly by co-financing R\&D-projects, indirectly by contributing to improve relevant infrastructure like technology centres. The European Social Fund (ESF) targets training measures for the unemployed and disadvantaged persons. The two other funds, the European Agricultural Guidance and Guarantee Fund (EAGGF) and the The Financial Instrument for Fisheries Guidance (FIFG) helps adapt and modernize the agriculture and fishing sectors. 
Whilst Structural Funds aim at large-scale structural transformation and may be regarded as "mainstream", the Innovative Actions Program of the ERDF provides disadvantaged regions with opportunities for experimentation. Between 2002 and 2006, one of the three strategic measures focuses on knowledge-based regional economies and technological innovation to help regions acquire competitive assets based on technological innovation through cooperation between the public sector, the bodies responsible for research, technological development and innovation as well as businesses with a view to creating efficient regional innovation systems (Inforegio, 2001).

The following overview regards only ERDF co-financed priorities of Objective 1 programmes which have explicitly innovation-oriented measures (see table 1). Due to a lack of comparable data at the level of measures, the data presented in table 1 are for priorities, so the amount actually spent on innovation support might be smaller.

\section{$=>$ TABLE 1}

The overview reveals that in most Objective 1 programmes innovation-oriented priorities account only for a small portion of the total support. Innovation has been granted the highest importance in Germany and Ireland and the lowest in Spain. Interestingly, the share of the EU contribution in the total programme cost is lower in the former than in the latter.

Differences in scope and content regarding the support for innovation in European Objective 1 programmes can either be due to different development strategies or to specific regional conditions causing particular problems and needs. Region-specific problems certainly exist, but there are some problems hampering innovation that seem to be general, at least at the national level. This can be concluded from the most recent Community Innovation Survey, CIS3 (Eurostat, 2004). Table 2 shows that the patterns of problems and needs of firms regarding their innovation activities are quite similar in all countries. Financial shortages and economic risks of innovation projects are the predominant barriers of firms everywhere. A further general problem, but less serious, is the lack of qualified personnel. It is interesting that inflexible regulations and standards are a widespread problem too, but here different approaches to regulation in the countries become obvious. Whereas $20 \%$ of the German firms indicated that this is a factor seriously hampering innovation, only $8 \%$ of the Irish firms were of the same opinion.

\section{$=>$ TABLE 2}

Apart from these general innovation barriers, are there also typical barriers in less developed regions which are the target of Objective 1 support? Usually, barriers in such regions are due to the low density of adequate innovation partners, the so-called deficiency of "organizational thinness". Isaksen (2003) identifies three basic types of regional innovation barriers: 1) 'Organizational thinness': The region lacks relevant specialized knowledge organizations and firms which can co-operate in or contribute to innovation projects. 2) 'Fragmentation': Relevant firms and other organizations exist but they do not interact. 3) 'Lock-in': Interactions between firms and other organizations exist but these ties are too rigid and strong, sticking to traditional approaches and suffocating innovation. Less developed 
regions like our case study Burgenland are usually confronted with the most serious deficiency - organizational thinness. Their economy is dominated by old industries, a lack of technologically advanced manufacturing firms and inadequate producer services as well as a lack of regional knowledge providers like universities and research centres. Their education and training infrastructure is weak and public support is often missing or ineffective. Important resources for innovation are lacking, especially adequately qualified personnel and venture capital. Applying Cooke's typology of regional innovation systems - based on the dimensions 'firm organization', comprising any kind of relation between firms and the relations with labour, 'policy organization', referring to the relations between public authorities and firms, 'infrastructure capacity', consisting of finance, public administration, science and research and 'institutional capacity' which means culture and social norms affecting the propensity to co-operate (Cooke et al., 2000) - less developed regions are on the lower end of each of them. It is not radically different needs than in more advanced regions that matters for less developed regions regarding innovation support, but the seriousness of barriers - preventing innovation to be started in the first place or to be finished - as well as the difficulties to remove them and the necessity to fit support activities into national and European frameworks.

\section{Case Study: Objective 1 Programme Burgenland}

Chapter 3 provided a general overview of the importance of innovation in Objective 1 programmes. This information, however, does not allow to assess how well these programmes meet firms' needs for innovation support. We will deal with this question in detail in a specific case: the Objective 1 programme of the Austrian province Burgenland.

\subsection{Burgenland - the Least Developed Province of Austria}

Burgenland has historically been a peripheral rural area characterized by an unfavourable industrial structure dominated by mature low-wage industries, slow economic development, a negative demographic trend, and high unemployment. Since the 1990s, the framework conditions for Burgenland have changed quite drastically due to the opening of the borders to Eastern Europe, Austria's accession to the European Union, and the stronger investment and trade relations between economies worldwide. As a consequence, the regional government had to adjust its economic policy. The possibility to access Structural Funds has played an important role in this context. The first EU co-financed Objective 1 programme 1995-1999 aimed at stimulating structural change through investment in infrastructure, modernising existing companies and attracting new businesses, complemented by technology-related measures such as technology centres and technology transfer. The current Objective 1 programme 2000-2006 has a stronger strategic focus on reducing the north-south disparities and a stronger thematic focus on innovation and qualification of human resources. ERDF interventions still target companies but now primarily in order to strengthen their innovation capacity. 
With $64 \%$ of the Austrian average GDP per capita in 1995, Burgenland's economic performance has been lagging significantly behind the other Austrian provinces; it has since risen to $68 \%$. Average annual growth rates are among the highest in Austria $6 \%$ in 1995 1999) and underline the recent positive economic development compared with the rest of Austria (5.5\% on average). In addition, there has been a strong sectoral shift, as the GDP per capita in the primary sector has been shrinking (-7.5\%) while those of the secondary and tertiary sectors have been expanding ( $8.2 \%$ and $7.0 \%$, respectively). Regarding research and development, however, Burgenland is still the weakest region in Austria. The extremely low share of $0.3 \%$ of $R \& D$ personnel and $0.2 \%$ of total R\&D expenditure (1998) can largely be explained by the lack of universities and research organizations as well as the unfavourable industrial structure.

The relative innovation performance of Burgenland's economy can be assessed by comparing the sectoral shift of innovation classes based on data from the recent Community Innovation Survey (CIS3) in Austria. For this purpose we have defined five innovation classes which are distinguished by the percentage of firms with product innovations in any industry. We have then compared the share of these classes in total employment and their growth between 1991 and 2001. Based on CIS3 the most innovative industries in manufacturing (i.e. those with more than $50 \%$ product innovators) are the chemical, electronics and automotive industries (with up to $95 \%$ in the case of chemicals). Less innovative but still above the average of the manufacturing sector (37\%) are the food, plastics and glass industries. The more innovative service industries (more than the sector-average of 33\% product innovators) are banking and insurance as well as data processing, research and development and engineering. All other manufacturing and service industries belong to the less innovative classes.

Corresponding to the general trend of decreasing employment in the manufacturing sector its share in total employment was lower in 2001 than in 1991 (see figure 2). In Austria only the most innovative industries could retain their employment share almost at the same level. In Burgenland, however, even the share of the most innovative industries has been decreasing. On the contrary, the importance of services has been growing. Yet while the share of the less innovative service industries in Austria was slightly lower in 2001 than in 1991, it has been increasing in Burgenland. This is due to the fact that the whole service sector in Burgenland has been growing stronger than in Austria.

\section{$=>$ FIGURE 2}

This shows that the structural changes in Burgenland are only partly in favour of more innovative industries. Innovative services have been growing stronger in Burgenland than in Austria, yet their share is still lower in this region than in Austria. A precarious development is the much stronger decline in the most innovative manufacturing industries in Burgenland than in Austria. 


\subsection{Innovation in Burgenland's Economy}

The findings in this chapter are based on a survey of innovative firms in Burgenland. The survey was conducted within the framework of the mid-term evaluation of the Objective 1 programme Burgenland at the end of 2003. Its aim was to analyse the process of innovation, the networks, problems and needs of innovative firms. Therefore the survey covers exclusively firms with at least one product innovation in the recent past, even if it was only a minor one, but no firms without any innovation activity. The questionnaire was sent to firms from manufacturing and selected service industries (consulting, engineering, software and information technology). We arrived at a number of 64 respondents of which 54 were fully usable for analysis. The response seems weak but it has to be considered that the number of firms in this region which are actually engaged in innovation is very small. CIS3-data for Austria show that only about one third of Austrian firms are innovative. Assuming that this ratio does not differ too much between Burgenland and the rest of Austria, we estimate the relevant response rate at about $10 \%$.

From the responding firms, 37 belong to the manufacturing sector, 17 to services. The industries of the manufacturing sector are rather well represented in the survey. There is only one exception - electrical and optical equipment - which is strongly overrepresented in the survey. Two sectors are underrepresented in the survey, services and construction. Regarding size most responding firms are small: 25 firms have less than 10 employees, 19 less than 50, 9 less than 250 and only a single firm is large.

In order to get information about the needs of regional firms regarding support for their innovation activities, we asked for the most serious barriers, i.e. problems actually preventing or having prevented at least one innovation project of the responding firms (see figure 3 ). Most frequently indicated were financial barriers: lack of public and private funds and too high taxes. Less important negative factors - problems which delay innovation projects but do not prevent them - are, in addition to the financial barriers, deteriorating market conditions, lack of distribution partners, lack of adequately qualified labour force and missing access to international markets. A lot of potentially important barriers came out to be negligible. About or more than $80 \%$ of the firms stated to have no problems regarding research (like missing research partners and inadequate access to international research programmes), consulting (insufficient legal and marketing services), infrastructure (inadequate IT-networks and transport links) and legal restrictions (rigid environmental and work standards). It is extremely unlikely, however, that this reflects the true situation. Often such answers are caused by unawareness of latent deficiencies.

\section{$=>$ FIGURE 3}

Regarding the external relations in the innovation process of the firms, we find that partners within the value chain - customers and suppliers - are the most important. In this respect our survey confirms an already well established fact. More remarkable is the strong role of public institutions providing financial support for innovation projects. As far as national and regional sources of public funds are concerned, co-funding is far more frequent in Burgenland than in the rest of Austria. But there is hardly any difference between 
Burgenland and the rest of Austria when we consider co-funding by the European Union (Structural as well as Framework Funds). In general, we find a rather traditional approach to the funding of innovation activities: Banks are by far more often involved in innovation projects than institutional providers of risk capital like venture capital funds. Concerning the diversity of the innovation networks, most firms in Burgenland have only few types of partners. It is, in particular, partners from research, training and education as well as technology transfer that are often missing. Comparing this result with CIS3 data for Austria it has to be concluded that firms in Burgenland are less willing or able to co-operate with such partners than firms in other parts of Austria. As far as the spatial dimension of the innovation networks is concerned, most firms have partners only in the region or in Austria. International relations are comparatively rare. Cross-border partnerships with firms in neighbouring Hungary, in particular, are extremely rare. Only a single firm indicated an innovation cooperation with a Hungarian supplier.

This shows that the innovation networks of firms in Burgenland are quite limited and should be expandable. Asking in detail which partners for their innovation projects are missing in the region shows that the most serious lack of regional partners concerns suppliers, followed by public support and risk capital (see figure 4). Institutions from the regional RTD infrastructure (e.g. technology centres, training and education as well as research organizations) are obviously far less often perceived as missing. Only the case of lacking a regional university was frequently mentioned as a problem.

\section{$=>$ FIGURE 4}

What are the types of innovation partners with which firms would like to establish new relations? Our survey shows that customers (48 indications) and suppliers (45) are by far the most frequently targeted. Banks follow with a distance (24). New partners from the service sector are less often mentioned (19) which is similar for public support and private risk capital (18 each). Partners from research are obviously hardly appreciated: Universities were mentioned 8 times, contract research 10 times and universities of applied sciences (technical colleges, Fachhochschulen) 11 times. We find that if there is any relevance for research partners then they have to be as applied as possible. Therefore there could be a more important role for respective education institutions, i.e. Fachhochschulen, in this context. Most firms expressed their intention to find new partners within the region (83 indications) or in Austria (87). To access new partners abroad is, in general, far less popular (39), but as far as Hungary is concerned, interest in new partners in this neighbouring country is comparatively strong (25).

\subsection{Are ERDF-Measures Appropriate for Supporting Innovation?}

Due to data constraints and the short period of time - too short for substantial effects to have taken place - we cannot directly assess the effects of EU-funds on the innovativeness of regional firms. Our survey data seem to indicate no considerable differences between firms with and those without support by EU-funds regarding the scope of innovation (products that 
either have been modified, are new for the firm or new to the market), the change of business activity and the entering of new markets. Furthermore, none of our respondents who have been supported by the EU has changed the core business activity in the past years. But with the available data we cannot test these hypotheses thoroughly by means of statistical analyses. Instead we have compared the activities of the innovation-related measures of Burgenland's Objective 1 programme with the problems and needs of regional firms concerning innovation in order to find out whether the programme addresses them adequately or not.

The Objective 1 programme of Burgenland comprises 6 priorities: 1) Manufacturing, 2) Research, technology and innovation, 3) Tourism and culture, 4) Agriculture, forestry and environmental protection, 5) Human resources, and 6) Technical support. In total the programme provides $270 \mathrm{~m} €$ of EU funds (ERDF, ESF, EAGGF). The first two priorities comprise measures that concern innovation. Priority 1 has an EU-budget of $88 \mathrm{~m} €$, priority 2 's is $29 \mathrm{~m} €$. Together they account for $44 \%$ of the Objective 1 programme. According to the objectives as laid down in the Single Programming Document (Amt der burgenländischen Landesregierung, 2001) all nine measures of these two priorities are aiming explicitly or implicitly at innovation. But as we will see in the following, the effects of many measures on innovation in Burgenland's economy are actually far weaker than intended.

Table 3 gives a brief overview of objectives and actual effects on problems and needs of regional firms regarding their innovation activities.

\section{$=>$ TABLE 3}

In addition to these objectives the programme is intended to stimulate start-ups. The target of 500 new firms during the programming period has been clearly missed so far. In the first two priorities only 4 start-ups have been recorded until June 2003.

Overall, the objectives are too ambitious considering the available funds. Actually, what is primarily supported in priority 1 are investments of firms aiming at modernization or extension of already existing plants. R\&D-projects, start-ups and co-operations, especially with research organizations, are far less frequent. The effects of the priority 1 measures on innovation are therefore rather weak.

Priority 2 is closer to innovation but only successful as far as R\&D projects - mainly in software and electronics - are concerned. Joint R\&D projects with research organizations, however, are rare. In general, network effects are weak. One priority 2 measure explicitly aims at supporting the emergence of regional clusters and the number of initiatives is actually large, but so far there are no substantial activities regarding building up of competence and joint learning. From the 11 cluster initiatives supported by ERDF-funds most focus on construction and timber (the others concern ceramics, metal products and water treatment). Many of these initiatives are closely related and it seems that a more coherent cluster approach would be reasonable. This means that support should be focused on a few strategic fields with clear objectives and plans how to achieve them, implying more substantial contributions of firms which want to participate. There are two basic weaknesses of the present cluster strategy in Burgenland: Firstly, too many initiatives are supported in a fragmented and piecemeal way, lacking strategic priorities and the integration in networks outside the region. (Linking with national, and international networks, however, is actually 
impeded by EU-rules concerning the area eligible for support.) Secondly, there is no strategy how clusters can become more than a mere list of firms (e.g. joint innovation projects, specific training schemes, information and marketing services for participating firms).

Infrastructure projects - primarily supported in the second priority - concern more or less the extending or setting up of technology centres. The aim of the measures is to provide facilities, but not to offer innovation-related and -supporting services like technology transfer, network-building, or innovation management consultancy. The establishment of a regional venture capital fund does certainly match an important need of many firms. The fund, however, is far too small to have wider effects on the regional economy's endowment with risk capital.

Table 3 suggests that the Objective 1 programme does not sufficiently target the really important needs and problems of firms regarding innovation. Table 4 shows that the share in the total Objective 1 programme of those projects that do target such needs and problems is very small - actually too small to have significant effects on the innovation capability and performance of the regional economy.

\section{$=>$ TABLE 4}

In total, only 25 projects (disregarding the qualification measures of the fifth priority supported by the ESF) have been targeting the most important problems or needs of firms' innovation activities until June 2003. Their total amount of committed investment (public and private) of $95.6 \mathrm{~m} €$ accounts for only $18 \%$ of the Objective 1 programme. Furthermore, most funds are used up for improving the regional technology infrastructure in Burgenland and for providing risk capital. But also these projects do not perfectly meet the firms' needs. The establishment and extension of technology and incubation centres concerns only the material investment in facilities, but not the range of services of these centres for SMEs that need specific innovation support. Our survey shows that many firms did not indicate any interest in relations with technology centres. This is no surprise considering the limited range of services of these centres today. Therefore new services have to be provided, but taking into consideration that often problems of firms are latent, i.e. they are not aware of certain deficiencies, they have to be offered proactively. This should become a much more important task of regional technology centres than it is today. As far as venture capital is concerned, the available funds are still far too small to have any significant effect on the endowment of the regional economy with risk capital.

Table 4 also shows that many important needs of firms in order to improve their innovation performance are hardly represented or not addressed at all. This applies in particular to network-oriented projects like research co-operations with science and clusters of firms jointly engaged in innovation activities. The number of such projects is negligible. Support for international and cross-border co-operations with Hungarian partners regarding innovation and marketing is missing completely. It is particularly this kind of support that would very likely raise the innovation performance of firms in Burgenland. This conjecture is confirmed by many findings of recent innovation research. The importance of networks for the success, even the emergence, of innovation projects of firms is a well established result in the literature. Innovation is almost always of a systemic nature (Kline \& Rosenberg, 1986), 
comprising networks at international, national (Lundvall, 1992; Nelson, 1993) and regional levels (Braczyk et al., 1998). Intensive direct personal communication is a frequent precondition for successful innovation co-operations (Nonaka \& Takeuchi, 1995). It enables the emergence of trust which is necessary for such relations (Malecki \& Oinas, 1999). And it helps to overcome the difficulties to exchange tacit knowledge (Cowan et al., 2000). Networks can involve a broad variety of organizations, private and public, business and science, manufacturing and services. Often more radical innovations require contributions from partners who follow different rationalities like firms and university departments (Kaufmann \& Tödtling, 2001). However, they are usually very difficult to be established, to be managed and, what is our concern here, to be initiated by public support. So far, at least in the case of the Objective 1 region Burgenland, EU structural funding has not been successful in this respect.

\section{Conclusions}

Analysing the data from our innovation survey as well as from the programme monitoring, we conclude that, overall, the Objective 1 programme Burgenland is too small, covers too broad a range of tasks and neglects too many crucial needs and problems to be really effective in stimulating innovation and, eventually, transforming Burgenland's economy to become more competitive and dynamic.

We think that one important reason for the inability of Structural Funds to stimulate innovation in Burgenland is the ambition to follow two rationales in a single programme. One strategic focus is convergence, closing the gap between poorly and strongly performing regional economies. The other strategic focus is competitiveness, raising the innovative performance of firms. Both rationales are not necessarily contradictory, but they need to be addressed with different sets of instruments. Trying to achieve both objectives within one programme with a relatively small budget is bound to miss one of them; at present, this applies to the stimulation of innovation. Regional development and innovation strategies in Burgenland have to be better integrated. Innovation should become a more important objective implying that not all parts of the province will benefit equally. And it is very important that Burgenland coordinates its activities with other regions in and beyond Austria. The innovation-oriented regional development strategy of such a small region has to focus on specific roles it can play in larger innovation networks beyond its boundaries.

A particular problem of less developed regions like Burgenland is the very small number of firms which have the capability to make effective use of the innovation support offered. Furthermore, such regions usually also lack research organizations, producer services and qualified labour. The low density prevents the emergence of comprehensive innovation networks within the boundaries of the region, and it is therefore very important to support the establishment of links of regional firms to innovation partners outside the region. This should be an explicit objective of innovation support in less developed regions.

The Structural Funds framework in its current design is not appropriate to stimulate innovation. Firstly, the operating principles of most Objective 1 measures are basically riskaverse. Institutions in charge of administrating these measures have no incentive to select 
more innovative and, as a consequence, more risky projects. Accordingly, low-risk singlefirm investment projects are predominant. Secondly, support is restricted to 'eligible', often very small regions. This applies clearly to our case, the region of Burgenland, which is small even for Austrian standards. Many network-oriented projects of innovation support (e.g. clusters, ICT-infrastructure) cannot be supported within these spatially restricted boundaries.

What is needed to raise the importance of Structural Funds for innovation-led structural change? The following recommendations are based on the case of the Objective 1 programme Burgenland and thus necessarily specific. Nevertheless, many concern general features of structural funding and are therefore of a more general interest regarding the design of EU regional policy.

At the strategic level the following changes seem necessary:

- Adjusting the mechanisms in a way that the support of higher-risk projects becomes more attractive for selection by the managing authorities. This concerns the project selection criteria, the controlling of projects, the monitoring of longer-term and indirect effects as well as more flexibility regarding the time schedule for using funds.

- Finding a viable compromise between reinforcing dynamic agglomeration and reducing regional disparities. A balanced support of innovative clusters, even if they are spatially concentrated in already well-performing cities and regions, on the one hand, and of innovation preconditions in lagging regions, on the other, seems to be necessary. The former should at least be as important as the latter.

Consequently, the following changes at the operational level seem to be most important:

- Support of innovation networks without spatial restriction.

- Preferred support of innovation projects at the expense of modernization and extension projects.

- Stronger focus on the services offered by technology and incubation centres, going beyond the mere provision of facilities.

- Elimination or relaxation of rigid financial rules like ' $n+2$ ' (funds committed but not paid out within two years are lost, the budget is reduced accordingly). Design of more flexible rules of financial control.

If Structural Funds focus more on stimulating innovation, they very likely will have stronger effects on structural change toward higher value-added and competitive industries than at present. The necessary adjustments, we conclude from the case of Burgenland's Objective 1 programme, are certainly feasible. However, they need to be accompanied by a more integrated development strategy of the region which has to be well coordinated with national research, technology and innovation policies and other regions' activities. 


\section{References}

AMT DER BURGENLÄNDISCHEN LANDESREGIERUNG (2001) Objective 1 Burgenland 2000-2006, Single Programming Document. Eisenstadt.

AYDALOT, P. (Ed) (1988) High technology industry and innovative environments. London: Routledge.

BRACZYK, H., COOKE, P. and HEIDENREICH, M. (Eds) (1998) Regional innovation systems. London: UCL Press.

COOKE, P., BOEKHOLT, P. and TÖDTLING, F. (2000) The governance of innovation in Europe. Regional perspectives on global competitiveness. London, New York: Pinter.

COWAN, R., FORAY, D. and DAVID, P.A. (2000) The explicit economics of codification and the diffusion of knowledge, Industrial and Corporate Change, 6, pp. 595-622.

DOHSE, D. (2000) Technology policy and the regions - the case of the BioRegio contest, Research Policy, 29, pp. 1111-1133.

ERP (2003) ERDF Monitoring, 6/2003. Vienna.

EUROPEAN COMMISSION (1995) Green paper on innovation. Brussels: CEC.

EUROPEAN COMMISSION (2004) A new partnership for cohesion - convergence, competitiveness, cooperation (third report on economic and social cohesion). Brussels: CEC.

EUROSTAT (2004) Innovation in Europe. Results for the EU, Iceland and Norway. Luxembourg: Office for Official Publications of the European Communities.

GRANDE, E. (2001) The erosion of state capacity and the European innovation policy dilemma A comparison of German and EU information technology policies, Research Policy, 30, pp. 905-921.

INFOREGIO (2001) The regions and the new economy. http://europa.eu.int/ comm/regional_policy/innovation/pdf/sheet/inforegio_en.html.

INFOREGIO (2004a) Understanding regional policy: How is it implemented? For whom? For what purpose? http://europa.eu.int/comm/regional_policy/intro/regions5_en.htm.

INFOREGIO (2004b) Regional development programmes $2000 \quad \mathbf{2 0 0 6}$. http://europa.eu.int/comm/regional_policy/country/prordn/search.cfm?gv_pay=ALL\&gv_ reg $=$ ALL\& gv_obj=1\&gv_the $=4 \& L A N=E N$.

ISAKSEN, A. (2003) National and regional contexts for innovation, in B.T. ASHEIM, A. ISAKSEN, C. NAUWELAERS and F. TÖDTLING (Eds) Regional innovation policy for small-medium enterprises, pp. 49-77. Cheltenham, Northampton: Edward Elgar.

KAUFMANN, A. and TÖDTLING, F. (2001) Science-industry interaction in the process of innovation: the importance of boundary-crossing between systems, Research Policy, 30, pp. 791-804.

KLINE, S.J. and ROSENBERG, N. (1986) An overview of innovation, in R. LANDAU and N. ROSENBERG (Eds) The positive sum strategy: harnessing technology for economic growth, pp. 275-307. Washington: National Academy Press.

LUNDVALL, B.-A. (Ed) (1992) National systems of innovation: towards a theory of innovation and interactive learning. London: Pinter.

MALECKI, E. and OINAS, P. (Eds) (1999) Making connections: technological learning and regional economic change. Aldershot: Ashgate. 
MIDELFART-KNARVIK, K.H. and OVERMAN, H.G. (2002) Delocation and European integration: is structural spending justified?, Economic Policy, 10, pp. 322-359.

NELSON, R.R. (Ed) (1993) National innovation systems: a comparative analysis. Oxford: Oxford University Press.

NONAKA, I. and TAKEUCHI, H. (1995) The knowledge creating company. New York: Oxford University Press.

SHARP, M. (1998) Competitiveness and cohesion - are the two compatible?, Research Policy, 27, pp. 569-588.

STATISTIK AUSTRIA (1992) Arbeitsstättenzählung 1991. Vienna.

STATISTIK AUSTRIA (2002a) Arbeitsstättenzählung 2001. Vienna.

STATISTIK AUSTRIA (2002b) 3. Europäische Innovationserhebung (CIS 3). Vienna. 


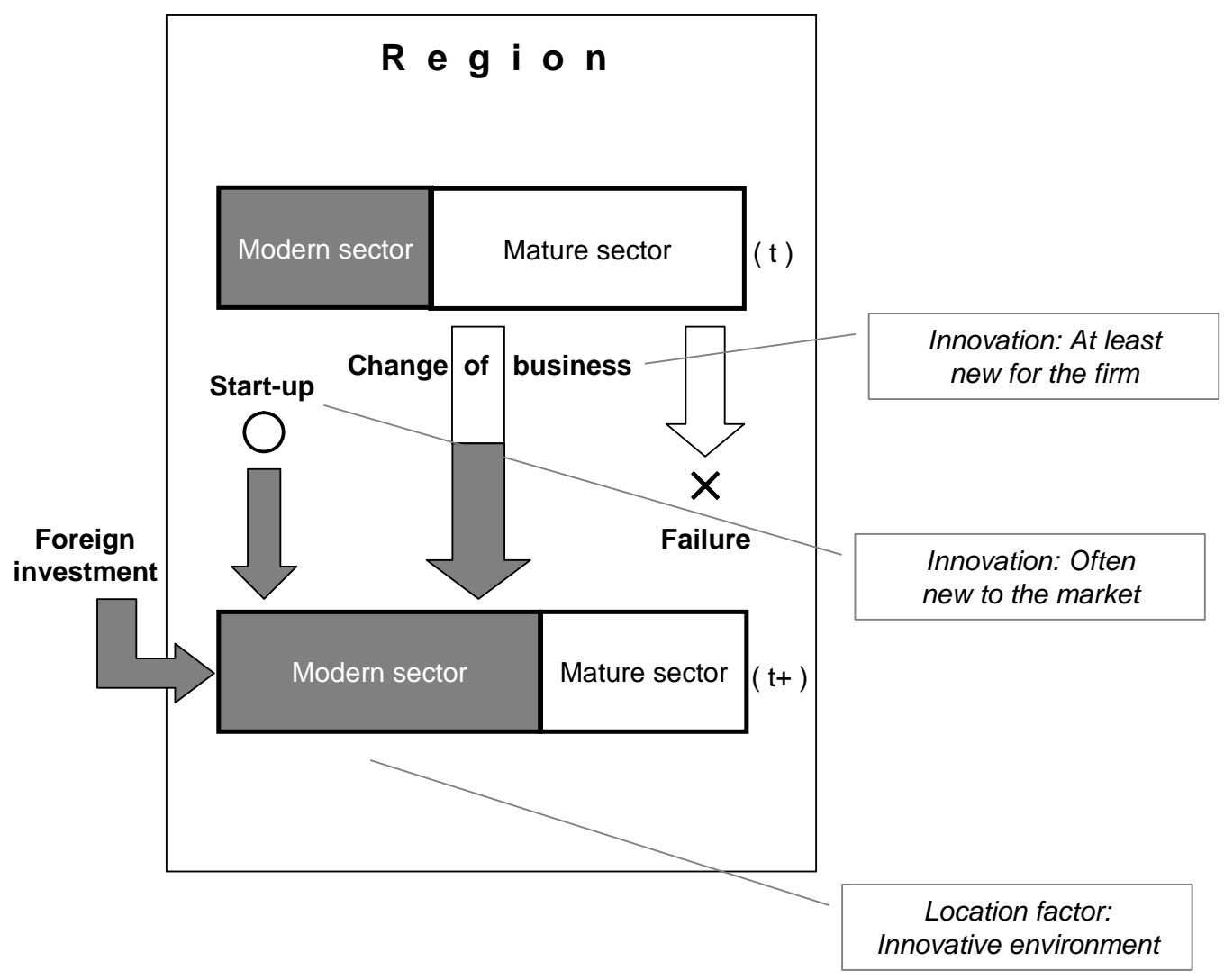

Figure 1. Structural change in a region's economy and the role of innovation. 
Table 1. Objective 1 programmes 2000-2006, innovation-related priorities ${ }^{1}$

\begin{tabular}{|c|c|c|c|c|}
\hline Country & Regional programme: priority & $\begin{array}{l}\text { Total cost } \\
\text { (million } € \text { ) }\end{array}$ & $\begin{array}{c}\text { EU } \\
\text { contribution } \\
(\%)\end{array}$ & $\begin{array}{l}\text { Share of } \\
\text { priority in pro- } \\
\text { gramme (\%) }\end{array}$ \\
\hline Austria & Burgenland: Research, technology and development & 73 & 41 & 8 \\
\hline \multirow[t]{5}{*}{ Germany } & East Berlin: Support for competitiveness & 1,361 & 17 & 64 \\
\hline & $\begin{array}{l}\text { Thüringen: Promotion of business competitiveness, especially } \\
\text { SMEs }\end{array}$ & 5,656 & 13 & 56 \\
\hline & Sachsen-Anhalt: Aid to enterprises & 3,841 & 24 & 44 \\
\hline & Mecklenburg-Western Pomerania: Aid for businesses & 1,534 & 24 & 28 \\
\hline & $\begin{array}{l}\text { Saxony: Promotion of business competitiveness, especially } \\
\text { SMEs }\end{array}$ & 5,424 & 23 & 48 \\
\hline \multirow[t]{4}{*}{ Greece } & $\begin{array}{l}\text { Western Greece Region: Restructuring \& expanding the } \\
\text { region's industrial base, promoting innovation }\end{array}$ & 93 & 33 & 12 \\
\hline & Thessaly: Productive environment & 157 & 31 & 17 \\
\hline & $\begin{array}{l}\text { Crete: Strengthening the region's role as a technological } \\
\text { development and research centre, moving innovation forward } \\
\text { and strengthening competitiveness }\end{array}$ & 98 & 39 & 13 \\
\hline & $\begin{array}{l}\text { Central Macedonia: Encouragement of innovation and } \\
\text { entrepreneurial spirit }\end{array}$ & 240 & 49 & 16 \\
\hline \multirow[t]{9}{*}{ Spain } & $\begin{array}{l}\text { Andalusia: The knowledge society (innovation, R\&D, } \\
\text { information society) }\end{array}$ & 342 & 75 & 29 \\
\hline & $\begin{array}{l}\text { Asturias: The knowledge society (innovation, R\&D, information } \\
\text { society) }\end{array}$ & 45 & 64 & 2 \\
\hline & $\begin{array}{l}\text { Canary Islands: Knowledge society (Innovation, R\&D, } \\
\text { Information society) }\end{array}$ & 120 & 71 & 4 \\
\hline & $\begin{array}{l}\text { Castile-La Mancha: Knowledge society (innovation, R\&D, } \\
\text { information society) }\end{array}$ & 59 & 70 & 2 \\
\hline & $\begin{array}{l}\text { Castile-Leon: Knowledge society (innovation, R\&D, } \\
\text { information society) }\end{array}$ & 120 & 70 & 2 \\
\hline & $\begin{array}{l}\text { Valencia: Knowledge society (innovation, R\&D, information } \\
\text { society) }\end{array}$ & 357 & 70 & 9 \\
\hline & $\begin{array}{l}\text { Extremadura: The knowledge society (innovation, R\&D, } \\
\text { information society) }\end{array}$ & 137 & 69 & 5 \\
\hline & $\begin{array}{l}\text { Galicia: The knowledge society (innovation, R\&D, information } \\
\text { society) }\end{array}$ & 172 & 75 & 3 \\
\hline & $\begin{array}{l}\text { Murcia: The knowledge society (innovation, R\&D, information } \\
\text { society) }\end{array}$ & 53 & 70 & 3 \\
\hline \multirow[t]{3}{*}{ France } & Guadeloupe: Productive environment and technology & 205 & 37 & 10 \\
\hline & $\begin{array}{l}\text { French Guiana: Developing research and higher education } \\
\text { through creation of a well established university centre }\end{array}$ & 50 & 35 & 7 \\
\hline & $\begin{array}{l}\text { Martinique: New information\&communication technologies, } \\
\text { technology transfer, innovation }\end{array}$ & 44 & 42 & 3 \\
\hline Ireland & $\begin{array}{l}\text { Border, Midland and Western Region: Local enterprise } \\
\text { development }\end{array}$ & 319 & 55 & 40 \\
\hline \multirow[t]{2}{*}{ UK } & $\begin{array}{l}\text { South Yorkshire: Stimulating the emergence of new growth, } \\
\text { high tech sectors }\end{array}$ & 633 & 33 & 21 \\
\hline & $\begin{array}{l}\text { West Wales and the Valleys: Developing Innovation and the } \\
\text { Knowledge-based Economy }\end{array}$ & 599 & 49 & 15 \\
\hline Total of & these programmes & 21,733 & 26 & 26 \\
\hline
\end{tabular}

${ }^{1}$ No relevant priorities in the following programmes: Attica, Epirus, Northern Aegean, Eastern Macedonia Thrace (all Greece), Ceuta, Melilla (all Spain), Apulia (Italy), Alentejo, Centroe, Norte (all Portugal).

Source: Inforegio (2004b): Regional development programmes 2000 - 2006. 
Table 2. Firms that cited the following hampering factors as highly important (2000), $\%$ of enterprises with innovation activity

\begin{tabular}{lrrrrrr}
\hline & Austria & Germany & Greece & Spain & Ireland & UK \\
\hline Excessive economic risk & 24 & 28 & 26 & 20 & 12 & 19 \\
Innovation costs too high & 29 & 38 & 30 & 33 & 17 & 27 \\
Lack of sources of finance & 20 & 28 & 33 & 20 & 15 & 21 \\
Organizational rigidities & 9 & 9 & 8 & 6 & 9 & 6 \\
Lack of qualified personnel & 16 & 29 & 18 & 14 & 13 & 14 \\
Lack of information on technology & 5 & 4 & 7 & 8 & 8 & 5 \\
Lack of information on markets & 7 & 6 & 7 & 9 & 9 & 9 \\
Inflexible regulation, standards & 13 & 20 & 16 & 11 & 8 & 19 \\
Lack of customer responsiveness & 5 & 8 & 9 & 11 & 11 & 14 \\
\hline
\end{tabular}

Source: Eurostat (2004): CIS3. 


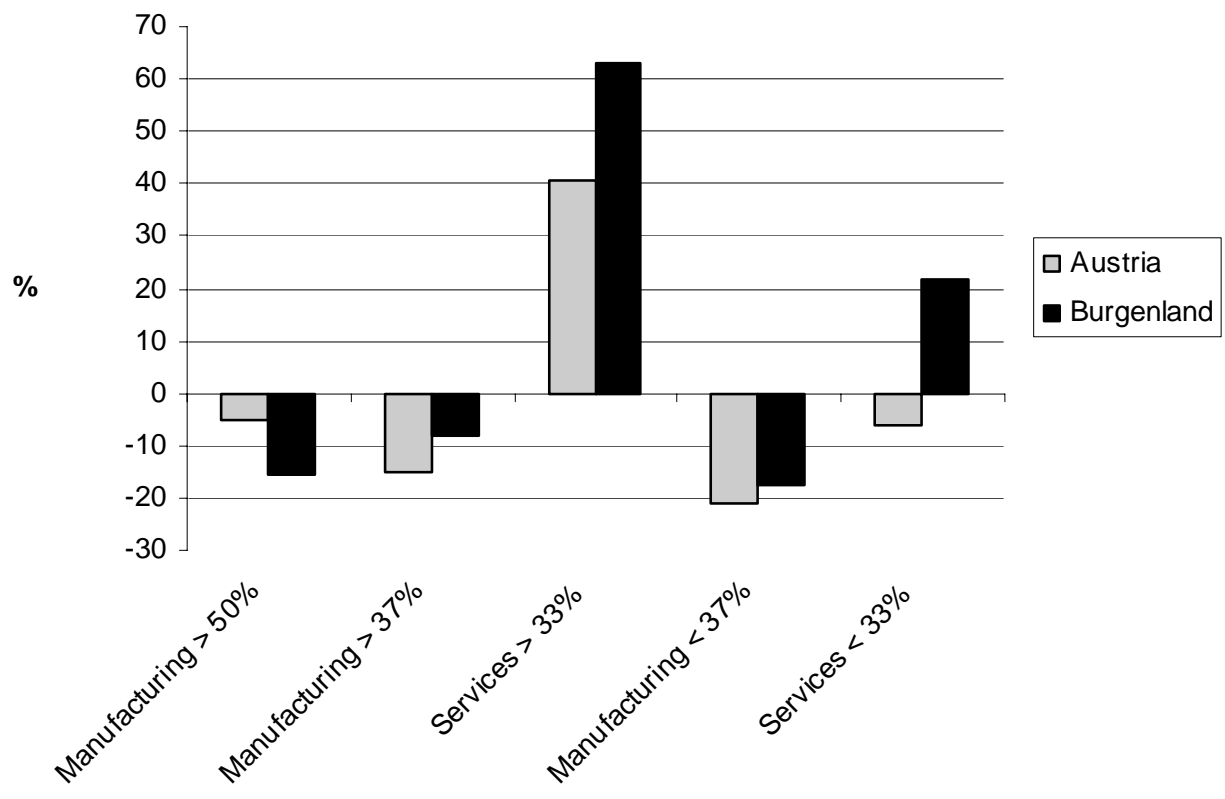

Figure 2. Employment growth in classes of innovative performance (i.e. industries with a share of firms with product innovations above or below certain thresholds like $50 \%$ and the mean share in the sector) 2001 / 1991. Source: Statistik Austria (2002b): 3. Europäische Innovationserhebung (CIS3, data for 1998 - 2000), Statistik Austria (1992): Arbeitsstättenzählung 1991, Statistik Austria (2002a): Arbeitsstättenzählung 2001. 


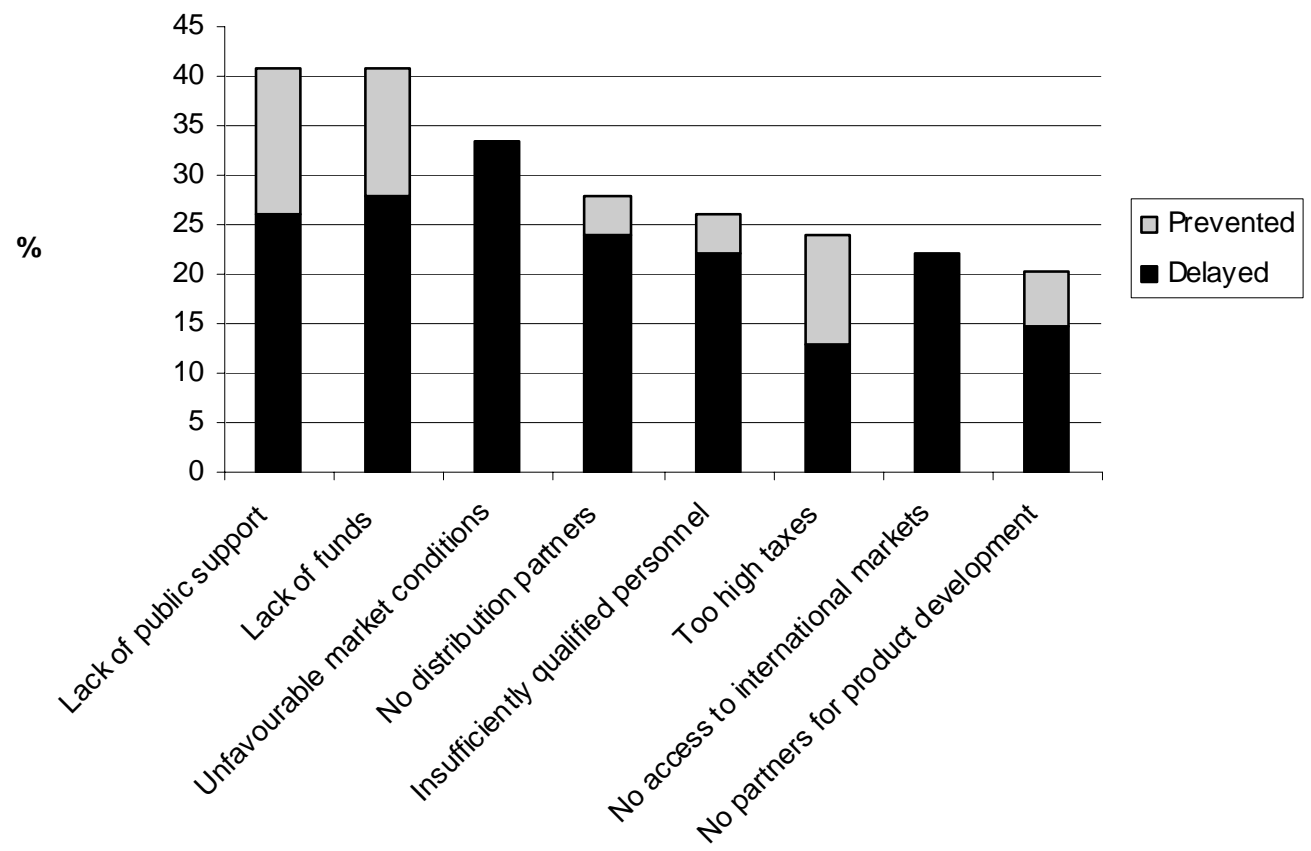

Figure 3. Important barriers constraining innovation. Source: Mid-term evaluation survey. 


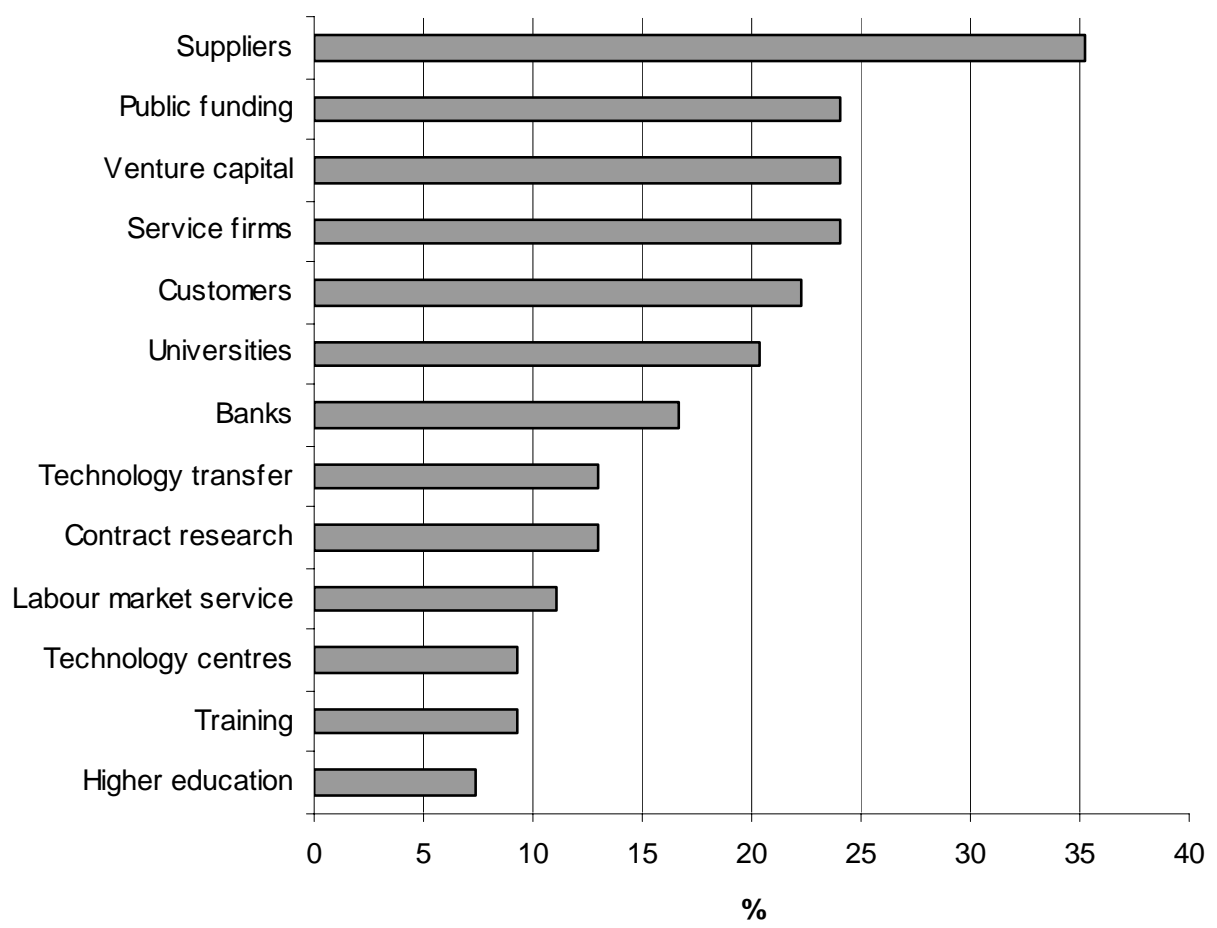

Figure 4. Innovation partners which are lacking in the region. Source: Mid-term evaluation survey. 
Table 3. Objectives and actual performance of innovation-related measures of the Objective 1 programme Burgenland until mid-term (June 2003)

\begin{tabular}{|c|c|c|c|}
\hline Measure & Tied $^{1}$ & Objective & Effects (mid-term evaluation) \\
\hline \multicolumn{4}{|l|}{1 Manufacturing } \\
\hline $\begin{array}{l}\text { 1.1 Strengthening } \\
\text { economic }\end{array}$ & $63 \%$ & $\begin{array}{l}\text { Supporting material and immaterial } \\
\text { investments that increase the }\end{array}$ & $\begin{array}{l}\text { Well accessed - } 16 \text { from targeted } 20 \\
\text { projects already realized. Mostly extension }\end{array}$ \\
\hline development & & $\begin{array}{l}\text { competitiveness of firms, the value added } \\
\text { of its products and that help to enter new } \\
\text { markets. Projects should also have } \\
\text { positive effects on the environment. }\end{array}$ & $\begin{array}{l}\text { and upgrading projects, only few start-ups. } \\
\text { Only one environmental project (biomass), } \\
\text { few effects of other projects on } \\
\text { environment. }\end{array}$ \\
\hline $\begin{array}{l}\text { 1.2 Support of SMEs } \\
\text { in structural change }\end{array}$ & $18 \%$ & $\begin{array}{l}\text { Supporting SMEs' capabilities concerning } \\
\text { co-operation, marketing, diversification } \\
\text { and internationalization. }\end{array}$ & $\begin{array}{l}\text { Smaller projects than expected, mainly } \\
\text { concerning setting up, extending or } \\
\text { modernizing a plant and consultancy. Few } \\
\text { co-operations. }\end{array}$ \\
\hline $\begin{array}{l}\text { 1.3 Priority- } \\
\text { supporting } \\
\text { infrastructure }\end{array}$ & $104 \%$ & $\begin{array}{l}\text { Improving locations to attract new firms } \\
\text { (transport, communication and other } \\
\text { infrastructure, business parks and fairs). }\end{array}$ & $\begin{array}{l}\text { Too many objectives regarding the } \\
\text { available budget. The total budget has } \\
\text { been used for only four projects } \\
\text { (extension of a business park, a new fair } \\
\text { building, two water projects). }\end{array}$ \\
\hline $\begin{array}{l}1.4 \text { Information } \\
\text { technology, } \\
\text { telecommunication }\end{array}$ & $38 \%$ & $\begin{array}{l}\text { Improving the access to data networks } \\
\text { and the use of the Internet. Stimulating } \\
\text { ICT R\&D-projects. }\end{array}$ & $\begin{array}{l}\text { No infrastructure projects so far (because } \\
\text { they are usually incompatible with the } \\
\text { regional boundaries). } 8 \text { ICT-related R\&D- } \\
\text { projects, mostly without co-operation. }\end{array}$ \\
\hline 1.5 Venture capital & $100 \%$ & $\begin{array}{l}\text { Establishing a venture capital fund to } \\
\text { provide risk capital to SMEs. }\end{array}$ & $\begin{array}{l}\text { The fund is insufficiently endowed with } \\
\text { capital. The fund is already used up by } \\
\text { only four investment projects. }\end{array}$ \\
\hline \multicolumn{4}{|c|}{2 Research, technology, innovation } \\
\hline $\begin{array}{l}2.1 \text { Clusters, } \\
\text { competence centres }\end{array}$ & $20 \%$ & $\begin{array}{l}\text { Stimulating the emergence of clusters. } \\
\text { Establishing competence centres (which } \\
\text { comprise firms and research } \\
\text { organizations). }\end{array}$ & $\begin{array}{l}\text { There are many cluster initiatives (11), but } \\
\text { they are lacking substantial activities, no } \\
\text { building-up of competence. Only a small } \\
\text { part of the budget has been used so far. }\end{array}$ \\
\hline $\begin{array}{l}2.2 \text { Technology and } \\
\text { incubation centres }\end{array}$ & $63 \%$ & $\begin{array}{l}\text { Establishing or extending technology and } \\
\text { incubation centres and a university of } \\
\text { applied sciences (Fachhochschule). }\end{array}$ & $\begin{array}{l}\text { The budget has been already used up } \\
\text { with the extension of one and the } \\
\text { establishment of two new technology } \\
\text { centres. }\end{array}$ \\
\hline $\begin{array}{l}2.3 \text { Innovative } \\
\text { services }\end{array}$ & $7 \%$ & $\begin{array}{l}\text { Supporting the introduction of innovative } \\
\text { services. }\end{array}$ & $\begin{array}{l}\text { Only very few (4) R\&D-projects so far (all } \\
\text { concerning software). }\end{array}$ \\
\hline 2.4 R\&D-projects & $47 \%$ & $\begin{array}{l}\text { Supporting research and development } \\
\text { projects, especially in co-operation with } \\
\text { research organizations. }\end{array}$ & $\begin{array}{l}\text { There are less projects (13) than } \\
\text { expected, but they are more expensive } \\
\text { (software and electronics). Only two } \\
\text { projects are in co-operation with science. }\end{array}$ \\
\hline
\end{tabular}

${ }^{1}$ ERDF-funds committed
Source: ERP (2003): ERDF monitoring. 
Table 4. Projects co-financed by the Objective 1 programme that are targeting needs of firms for innovation support

\begin{tabular}{|c|c|c|c|c|}
\hline Needs & $\begin{array}{l}\text { Stated / } \\
\text { Latent }^{1}\end{array}$ & $\begin{array}{c}\text { Projects targeting } \\
\text { this need }\end{array}$ & $\begin{array}{l}\text { Project volume } \\
\qquad(\mathrm{m} €)^{2}\end{array}$ & $\begin{array}{l}\text { Share in pro- } \\
{\text { gramme }(\%)^{2}}^{2}\end{array}$ \\
\hline $\begin{array}{l}\text { Co-operation with research } \\
\text { organizations }\end{array}$ & $\mathrm{L}$ & 3 & 2.0 & 0.4 \\
\hline Development co-operation with firms & $\mathrm{S}$ & 2 & 2.0 & 0.4 \\
\hline Technology transfer & $\mathrm{L}$ & 1 & 1.4 & 0.3 \\
\hline $\begin{array}{l}\text { Technology centres, applied sciences } \\
\text { (Fachhochschulen) }\end{array}$ & L & 5 & 39.4 & 7.5 \\
\hline Suppliers nearby & $\mathrm{S}$ & 11 & 0.6 & 0.1 \\
\hline Venture capital & $\mathrm{S}$ & 1 & 30.0 & 5.7 \\
\hline Distribution partners & $\mathrm{S}$ & 0 & - & - \\
\hline International partners & $\mathrm{S}$ & 0 & - & - \\
\hline Cross-border partnerships & $\mathrm{L}$ & 0 & - & - \\
\hline New sales markets & S & $?$ & - & - \\
\hline New technology for product innovation & S & 2 & 6.2 & 1.2 \\
\hline Qualified personnel & $\mathrm{s}$ & $?^{3}$ & $<14.0^{3}$ & $<2.7^{3}$ \\
\hline
\end{tabular}

${ }^{1}$ Stated: explicitly mentioned by at least a quarter of the firms. Latent: important factors contributing to successful innovation (deduced from research), but not mentioned by $25 \%$ or more of the firms.

${ }^{2}$ Total project volume comprising EU-funds as well as national, regional and private funds (1/2000 - 6/2003).

${ }^{3}$ Three measures of priority 5 (Human resources), funded by ESF, aim at improving qualification. These measures do not only support this objective, therefore the effective amount is less than presented in the table (no detailed data available).

Source: Mid-term evaluation. 